Sains Peternakan Vol. 5 (1), Maret 2007: 1-9

\title{
Pengaruh Suplementasi Ampas Tahu, Ampas Tempe dan Ampas Kecap dalam Ransum Terhadap Performan Domba Lokal Jantan
}

\author{
E. Handayanta \\ Jurusan Peternakan, Fakultas Pertanian, Universitas Sebelas Maret \\ Jl. Ir. Sutami 36 A, Kentingan, Surakarta \\ Email: ekahandayanta@yahoo.com
}

\begin{abstract}
ABSTRAK
Penelitian ini bertujuan untuk mengetahui pengaruh suplementasi ampas tahu, ampas tempe dan ampas kecap dalam ransum terhadap performan domba lokal jantan. Penelitian dilaksanakan selama tiga bulan dari Juli sampai Okrtober 2006 di Mini Farm Jurusan Petemakan, Fakultas Pertanian Universitas Sebelas Maret yang berlokasi di Jatikuwung, Gondangrejo, Karanganyar. Sebanyak 12 ekor domba lokal jantan dengan bobot badan ratarata $15,86 \pm 0,93 \mathrm{~kg}$ dibagi dalam empat macam perlakuan dan tiga ulangan, setiap ulangan terdiri dari satu ekor domba. Ransum yang digunakan berupa rumput Raja sebagai pakan basal dan diberikan sebesar $4 \%$ dari berat badan dan pakan suplemen berupa ampas tahu, ampas tempe dan ampas kecap. Perlakuan yang diberikan berupa pemberian pakan suplemen, masing-masing adalah tanpa suplemen (RO), 250 gram ampas tahu (R1), 250 gram ampas tempe (R2) dan 250 gram ampas kecap (R3). Variabel yang diamati meliputi konsumsi pakan, kecernaan Bahan Kering (BK), kecernaan Bahan Organik (BO), konsumsi Protein Kasar (PK), konsumsi energi, pertambahan bobot badan harian (PBBH) dan konversi pakan. Semua data dianalisis dengan analisis variansi Rancangan Acak Lengkap (RAL) pola searah, kecuali PBBH dianalisis dengan analisis kovariansi. Hasil_yang berbeda nyata dilanjutkan dengan uji Duncan. Hasil penelitian menunjukkan bahwa rerata dari keempat macam perlakuan vaitu P0, P1, P2 dan P3 berturut-turut untuk konsumsi pakan 430,52; 720,44; 704,44; 549,08 gram/ekor/hari; kecernaan BK (\%) 61,07; 72,46; 69,68; 63,60 ; kecernaan BO (\%) 64,41; 74,94; 72,41; 64,71; konsumsi PK 47,66; 106,77; 85,83; 73.70 gram/ekor/hari; konsumsi TDN 281,82; 482,65;432,67; 330,83 gram/ekor/hari, PBBH 50,00; 130,00; 116,19; 38.10 gram/ekor/hari dan konversi pakan 8,74; 5,61; 6,06; 15,2. Hasil analisis statistik menunjukkan bahwa pakan suplementasi berpengaruh sangat nyata $(\mathrm{P}<0,01)$ terhadap semua variabel yang diamati. Kesimpulan penelitian ini adalah suplementasi ampas tahu dan ampas tempe mampu meningkatkan performan, sedangkan ampas kecap tidak mampu meningkatkan performan domba lokal jantan.
\end{abstract}

Kata kunci: domba, ampas tahu, ampas tempe, ampas kecap, performan

The Effect of Supplementation of Tofu Waste, Tempe Waste and Soy Sauce Waste in Ration on Male Local Sheep Performance

ABSTRACT 

The aim of this research to determine the effect of supplementation of tofu. tempe, and soy sauce waste in ration on male local sheep performance. This research was carried out during three month, take place on July until October 200 E in Minifarm Dept. of Animal Science, Agriculture Faculty of Sebelas Maret University, located in Jatikuwung. Gondangrejo, Karanganyar. It used 12 male local sheeps with average body weight of $15.86 \pm 0.93 \mathrm{~kg}$, divided into four treatments and three replications, each replication consist of one sheep. The ration consisted of king grass only as basal diet, as many as four percent base on body weight. The treatment given is in the form of feed supplement, that namely without supplement (RO), 250 gram tofu waste (R1), 250 gram tempe waste (R2), and 250 gram soy sauce waste (R3). The data variables collected were feed consumption, dry and organic matter digestibility, crude protein consumption, energy consumption, average daily gain, and feed conversion ratio. All of data except average daily gain was analyzed by completely randomized design one way classification. While average daily gain was analyzed by covariance analyze. The result were significant followed by Duncan new multiple range test. The result showed that average of $R 0, R I, R 2$ and $R 3$ for feed consumption 430.52; 720.44; 704.44; 549.08 gram/day, dry matter digestibility (\%) 61,07; 72,46; 69,68: 63,60, organic matter digestibility (\%) 64,41: 74,94; 72.41; 64,7 1, crude protein consumption $47.66 ; 106.77 ; 85.83 ; 73.70$ gram/day, energy consumption 281.82; 482.65; 432.67; $330.83 \mathrm{gram} /$ day, average daily gain 50.00.1X00: $116.19 ; 38.10 \mathrm{gram} /$ day and feed conversion ratio $8.74 ; 5.61 ; 6.06 ; 15.2$. The result of variance analyze showed that feed supplementation have highly significant effect $(P<0.01)$ on all of the data variable colected. Conclusion of this research was supplementation of tofu waste and tempe waste could improved performance, while soy sauce waste could not improved the performance of male local sheep.

Key words : sheep, tofu waste, tempe waste, soy sauce waste, performance

\section{PENDAHULUAN}

Usaha peternakan merupakan salah satu jenis usaha yang memproduksi bahan pangan sumber protein hewani, seperti daging, telur dan susu. Salah satu jenis ternak penghasil daging adalah domba lokal yang merupakan domba asli Indonesia. Pada umumnya domba-domba tersebut dipelihara dalam kondisi yang sederhana (tradisional), dan rumput digunakan sebagai pakan utamanya, sehingga produksinva rendah. Oleh karena itu, untuk meningkatkan produktifitas ternak domba tersebut diperlukan tambahan pakan dalam ransumnya dalam bentuk pakan suplemen. Penambahan pakan suplemen dalam ransum memungkinkan ternak domba mengkonsumsi pakan yang lebih baik nilai gizinya dan lebih palatabel. Pakan suplemen dapat berupa bahan pakan yang tinggi kandungan energi atau proteinnya Pemberian pakan berenergi tinggi atau konsentrat pada domba terbukti dapat meningkatkan pertumbuhan, produksi daging dan bobot karkas (Soeparno dan Davies, 1987). Namun demikian, pemberian konsentrat dalam jumlah yang tinggi dalam ransum perlu diperhatikan secara seksama, karena disamping menentukan tinggi rendahnya produksi dan pertumbuhan, juga dapat menentukan besar kecilnya keuntungan. Seperti diketahui bahwa dalam usaha peternakan 70 sampai $80 \%$ biaya produksi adalah biaya pakan. Oleh karma itu, untuk mendapatkan keuntungan dari usaha peternakan domba diperlukan upaya menekan biaya pakan 

tanpa mempengaruhi tingkat produksi yang dihasilkan. Upaya yang dapat dilakukan adalah dengan menggunakan bahan pakan yang berasal dari limbah industri pengolahan hasil-hasil pertanian yang tidak berkompetisi dengan kebutuhan manusia, ternak ruminansia dan atau unggas. Bahan tersebut diharapkan tidak bersaing dengan kebutuhan manusia, mudah didapat, harga relatif murah dan tersedia dalam jumlah yang besar. Beberapa contoh bahan tersebut antara lain ampas tahu, tempe dan kecap.

Ampas tahu, tempe dan kecap merupakan limbah pengolahan kedelai menjadi beberapa produk seperti tahu, tempe dan kecap. Ampas-ampas tersebut masingmasing mengandung nutrien yang cukup tinggi, khususnya kandungan PK dan energi (TDN), masing-masing $18,22 \%$ dan $66,83 \%$ (Handayanta, 1999); 11,58\% dan 73,85\% (Anonimus, 1985) dan 23,5\% dan 87\% (Siregar, 1994). Kandungan nutrien dalam ampas-ampas tersebut memiliki potensi untuk digunakan sebagai pakan ternak, khususnya melengkapai pakan domba yang hanya berupa rumput saja.

Dari uraian diatas dapat diduga bahwa pemberian pakan suplemen dalam ransum yang berbasis rumput Raja dapat meningkatkan performan ternak domba. Oleh karena itu, perlu dilakukan penelitian tentang pengaruh suplementasi ampas tahu, tempe dan kecap dalam ransum terhadap performan domba lokal jantan.

\section{METODE PENELITIAN}

\begin{tabular}{lr}
\multicolumn{2}{c}{ Penelitian ini dilaksanakan di Mini } \\
Farm Jurusan Peternakan, \\
Pertanian Universitas Sebelas Maret
\end{tabular} Surakarta yang berlokasi di Jatikuwung, Gondangrejo, Karanganyar selama tiga bulan mulai bulan Juli sampai Oktober 2006. Analisis proksimat pakan dan sisa pakan dilakukan di Laboratorium Pangan dan Gizi, Pusat Studi Pangan dan Gizi, Universitas Gadjah Mada, Yogyakarta, sedangkan analisis BK dan BO feses di Laboratorium Nutrisi dan Makanan Ternak, Jurusan Peternakan Fakultas Pertanian, UNS, Surakarta.

Penelitian ini menggunakan 12 ekor domba lokal jantan dengan best badan (BB) rata-rata $15,86 \pm 0,93 \mathrm{~kg}$. Dombadomba tersebut sebelum digunakan diberi obat cacing merk Verm-O dengan dosis 1 tablet $/ 50 \mathrm{~kg}$ BB melalui mulut (per oral) untuk menghilangkan parasit dalam saluran pencernaan.

Ransum basal yang digunakan dalam penelitian ini berupa rumput Raja yang diberikan sebesar $4 \%$ dari BB domba dan pakan suplemen berupa ampas tahu, tempe dan kecap. Ampas tahu diperoleh dari daerah Pucang Sawit, ampas tempe dari daerah Pajang dan ampas kecap dari perusahaan kecap PT. Lombok Gandaria. Sebelum digunakan, ampa-ampas tersebut dijemur di bawah sinar matahari secara langsung sampai kering.

Kebutuhan nutrien domba lokal jantan dan kandungan nutrien bahan pakan penyusun ransum perlakuan tertera pada Tabel 1 dan Tabel 2.

Tabel 1. Kebutuhan Nutrien Domba BB $15 \mathrm{~kg}$

\begin{tabular}{lc}
\hline \hline \multicolumn{1}{c}{ Nutrien } & Kebutuhan (\%) \\
\hline Energi (TDN) & 67,85 \\
Protein Kasar (PK) & 8,30 \\
Kalsium (Ca) & 0,51 \\
Phospor (P) & 0,33 \\
\hline
\end{tabular}



Tabel 2. Kandungan Nutrien Bahan Pakan untuk Ransum

\begin{tabular}{|c|c|c|c|c|c|c|}
\hline Bahan Pakan & $\mathrm{BK}$ & PK & $\overline{\mathrm{SK}}$ & $\overline{\mathrm{LK}}$ & $\mathrm{BETN}^{\mathrm{I}}$ & $\mathrm{TDN}^{1 /}$ \\
\hline Rumput Raja & 92,33 & 11,07 & 58,05 & 2,84 & 11,74 & 65,46 \\
\hline Ampas Tahu & 90,37 & 23,03 & 26,97 & 12,28 & 33,72 & 70,35 \\
\hline Ampas Kecap & 89,89 & 25,76 & 14,99 & 4,25 & 17,52 & 32,94 \\
\hline Ampas Tempe & 90,71 & 14,53 & 54,16 & 2,54 & 26,33 & 52,91 \\
\hline
\end{tabular}

Sumber : Hasil analisis Lab. Pangan dan Gizi, Pusat Studi Pangan dan Gizi. Universitas Gadjah Mada. Yogyakarta (2006)

${ }^{1)}$ Hasil perhitungan sesuai petunjuk Hartadi et al., (1990)

Kandang yang digunakan dalam penelitian adalah kandang panggung individual sebanvak 12 buah dengan ukuran masing-masing $100 \mathrm{~cm}$ x $75 \mathrm{~cm}$ yang dilengkapi dengan tempat pakan dari kotak papan dan tempat minum yang berupa ember plastik. Peralatan lain yang digunakan adalah timbangan gantung kapasitas $25 \mathrm{~kg}$ dengan kepekaan masing-masing $0,1 \mathrm{~kg}$ untuk menimbang domba dan timbangan digital kapasitas $5 \mathrm{~kg}$ dengan kepekaan 1 gram untuk menimbang pakan, sisa pakan dan feses. Kandang dan peralatan sebelum digunakan terlebih dahulu dibersihkan dan dilakukan desinfeksi dengan disemprot menggunakan larutan Lysol dengan dosis 15 $\mathrm{ml} / \mathrm{l}$ air. Hal ini dilakukan untuk membunuh parasit yang dapat mengganggu domba.

Penelitian ini dilakukan secara eksperimental. Pakan basal yang diberikan berupa rumput Raja sebesar 4\% dari BB, sedangkan perlakuan yang diberikan adalah suplementasi ampas tahu, tempe dan kecap dalam ransum, masingmasing besarnya seperti tertera pada Tabel 3 .

Tabel 3. Susunan Ransum Perlakuan

\begin{tabular}{cll}
\hline \hline \multicolumn{1}{c}{ Perlakuan } & \multicolumn{1}{c}{ Ransum Perlakuan } \\
P0 & Rumput Raja (Kontrol) \\
P1 & Rumput Raja +250 gram Ampas Tahu \\
P2 & Rumput Raja +250 gram Ampas Tempe \\
Rumput Raja +250 gram Ampas Kecap
\end{tabular}
ad libitum.

Tahap koleksi data dilakukan selama 10 minggu setelah masa adaptasi. Kegiatan

Analisis Data 

Parameter yang diamati dalam penelitian ini meliputi: konsumsi pakan, kecernaan BK (KcBK), kecernaan bahan organik (KcBO), konsumsi PK, konsumsi energi (TDN), pertambahan bobot badan harian $(\mathrm{PBBH})$ dan konversi pakan. Semua data yang diperoleh dianalisis variansi berdasarkan Rancangan Acak Lengkap (RAL) pola searah, sedangkan PBBH dianalisis kovariansi. Hasil berbeda nyata dilanjutkan dengan uji beda antar ratarata dengan Duncan (Duncans Multiple Range Test) (Steel dan Torrie, 1981).

\section{HASIL DAN PEMBAHASAN}

Performan atau kinerja domba hasil penelitian yang meliputi konsumsi pakan, KcBK, KcBO, konsumsi PK, konsumsi TDN, PBBH, dan konversi pakan tertera pada Tabel 5.

\section{Konsumsi Pakan}

Hasil analisis variansi menunjukkan bahwa konsumsi BK dari keempat macam perlakuan adalah berbeda sangat nyata $(\mathrm{P}<0,01)$. Hal ini berarti bahwa konsumsi pakan sangat dipengaruhi oleh macam pakan suplemen.

Hasil uji lanjut Duncan menunjukkan bahwa rerata konsumsi pakan antara P0 dengan P3 berbeda tidak nyata, tetapi berbeda sangat nyata $(\mathrm{P}<0,01)$ antara $\mathrm{P} 1$ dengan P2. Sedangkan antara P1, P2 dan P3 berbeda tidak nyata. Domba yang tidak mendapatkan pakan suplemen menunjukkan konsumsi pakan yang lebih rendah dibandingkan dengan domba yang mendapatkan pakan suplemen.

Konsumsi pakan P3 dengan P0 berbeda tidak nyata, hal ini diduga pakan suplemen ampas kecap kurang disukai oleh domba dibandingkan ampas ampas tahu maupun ampas tempe, karena mempunyai rasa asin. Menurut Wahju (1992), rasa (taste) dapat menentukan banyaknya pakan yang dikonsumsi dan ternak ruminansia lebih menyukai pakan yang memiliki rasa manis dan hambar daripada rasa asin atau pahit (Kartadisastra (1997). Pakan suplemen yang berupa ampas tahu dan ampas tempe sangat disukai (palatabel) oleh ternak serta dapat meningkatkan konsumsi BK. Domba dengan pakan suplemen berupa ampas tahu menunjukkan konsumsi pakan paling tinggi diantara keempat macam perlakuan, walaupun secara statistik berbeda tidak nyata dengan ampas tempe. Hal ini diduga ampas tahu dan ampas tempe mempunyai tingkat palatabilitas yang tinggi bagi ternak.

Tabel 4. Performan atau Kinerja Domba Hasil Penelitian

\begin{tabular}{lcccc}
\hline \multirow{2}{*}{ Uraian } & \multicolumn{4}{c}{ Perlakuan } \\
\cline { 2 - 5 } & R0 & RI & R2 & R3 \\
\hline Rata-rata BB awal (kg/ekor) & & & & \\
Rata-rata BB akhir (kg/ekor) & & & & \\
Konsumsi BK (kg/ekor/hari) & $430,52^{\mathrm{A}}$ & $720,44^{\mathrm{B}}$ & $704,44^{\mathrm{B}}$ & $549,08^{\mathrm{AB}}$ \\
KcBK (\%) & $61,07^{\mathrm{A}}$ & $72,46^{\mathrm{B}}$ & $69,68^{\mathrm{B}}$ & $63,60^{\mathrm{A}}$ \\
KcBO(\%) & $64,41^{\mathrm{A}}$ & $74,94^{\mathrm{B}}$ & $72,41^{\mathrm{B}}$ & $64,71^{\mathrm{A}}$ \\
Konsumsi TDN (kg/ekor/hari) & $281,82^{\mathrm{A}}$ & $482,65^{\mathrm{C}}$ & $432,67^{\mathrm{BC}}$ & $330,83^{\mathrm{AB}}$ \\
Konsumsi PK (kg/ekor/hari) & $47,66^{\mathrm{A}}$ & $106,77^{\mathrm{C}}$ & $85,83^{\mathrm{B}}$ & $73,70^{\mathrm{B}}$ \\
Rata-rata PBBH (kg/ekor/hari) & $50,00^{\mathrm{A}}$ & $130,00^{\mathrm{B}}$ & $116,19^{\mathrm{B}}$ & $38,10^{\mathrm{A}}$ \\
Konversi Pakan & $8,74^{\mathrm{A}}$ & $5,61^{\mathrm{A}}$ & $6,06^{\mathrm{A}}$ & $15,20^{\mathrm{B}}$ \\
\hline
\end{tabular}

Keterangan: ${ }^{A, B, C}$ Rerata yang diikuti superskrip yang berbeda menunjukkan perbedaan yang sangat nyata $(\mathrm{P}<0,01)$ 

Handayanta (2004) menjelaskan bahwa besarnya konsumsi pakan menunjukkan palatabilitas dan nilai kualitas pakan tersebut dan palatabilitas pakan merupakan salah satu faktor penting yang dapat mempengaruhi tingkat konsumsi pakan (Kartadisastra, 1997).

\section{Konsumsi Protein Kasar (PK)}

Hasil analisis variansi menunjukkan bahwa konsumsi PK dari keempat macam perlakuan adalah berbeda sangat nyata $(\mathrm{P}<0,01)$. Hal ini berarti bahwa konsumsi PK sangat dipengaruhi oleh macam perlakuan pakan suplemen. Hasil uji lanjut Duncan menunjukkan bahwa rerata konsumsi protein antara $\mathrm{P} 0$ dengan $\mathrm{P} 1$. dan $\mathrm{P} 2$ dan $\mathrm{P} 3$ berbeda sangat nyata $(\mathrm{P}<0,01)$, sedangkan antara P1 dengan P2 dan P3 juga berbeda sangat nyata $(\mathrm{P}<0,01)$, sedangkan antara P2 dan P3 berbeda tidak nyata.

Perbedaan konsumsi PK ini menunjukkan bahwa domba yang diberi pakan suplemen menunjukkan tingkat konsumsi PK lebih tinggi dibandingkan domba tanpa pemberian pakan suplemen. Konsumsi PK dipengaruhi oleh banyaknya konsumsi pakan dan kandungan PK bahan pakan tersebut. Semakin tinggi konsumsi pakan dan kandungan PK bahan pakan maka semakin tinggi pula konsumsi protein kasar. Kamal (1994) menyatakan bahwa banyaknya pakan yang dikonsumsi akan mempengaruhi besarnya nutrien lain yang dikonsumsi, sehingga semakin banyak pakan yang dikonsumsi akan meningkatkan konsumsi nutrien lain.

Ampas tahu, tempe dan kecap mempunyai kandungan protein yang lebih tinggi daripada rumput Raja. Handayanta (2004) menyatakan bahwa semakin tinggi kandungan PK dalam ransum, maka semakin tinggi konsumsi PK. Domba dengan pakan suplemen ampas tahu mempumyai rerata konsumsi PK paling tinggi dan secara statistik berbeda sangat nyata $(\mathrm{P}<0,01)$ dengan rerata konsumsi $\mathrm{PK}$ pada domba lainnya. Hal ini selaras dengan rerata konsumsi $\mathrm{BK}$ pakan pada domba tersebut serta kandungan PK ampas tahu juga tinggi, yaitu sebesar $23,03 \%$.

\section{Konsumsi Energi (TDN)}

Hasil analisis variansi menunjukkan bahwa konsumsi energi dari keempat macam perlakuan adalah berbeda sangat nyata $(\mathrm{P}<0,01)$. Hal ini berarti bahwa konsumsi energi (TDN) sangat dipengaruhi oleh macam perlakuan pakan suplemen. Hasil uji lanjut Duncan menunjukkan bahwa rerata konsumsi TDN antara R0 dengan R1 dan R2 berbeda sangat nyata $(\mathrm{P}<0,01)$, tetapi dengan $\mathrm{R} 3$ berbeda tidak nyata, sedangkan antara R1 dengan R2 dan R2 dengan R3 berbeda tidak nyata tetapi antara R1 dengan $\mathrm{R} 3$ berbeda sangat nyata $(\mathrm{P}<0,01)$.

Perbedaan yang tidak nyata antara rerata konsumsi energi (TDN) antara P0 dengan P3 kemungkinan disebabkan oleh rerata konsumsi BK pakan yang berbeda tidak nyata serta kandungan energi (TDN) ampas kecap juga rendah yaitu 32,94\%. Hal ini sesuai pendapat Kamal (1994) yang menyatakan bahwa banvaknya pakan yang dikonsumsi akan mempengaruhi besarnya nutrien lain yang dikonsumsi. Lebih lanjut Adiwinarti et al. (2001) dan Firdus et al. (2004) menyatakan bahwa tingkat konsumsi energi sejalan dengan tingkat konsumsi BK yaitu dengan meningkatnya konsumsi BK pakan maka konsumsi energi juga makin meningkat. Konsumsi energi (TDN) dipengaruhi oleh konsumsi pakan dan kandungan energi (TDN) dalam bahan pakan tersebut.

Domba dengan pakan suplemen berupa ampas tahu mempunyai rerata konsumsi energi (TDN) paling tinggi kemudian diikuti domba dengan pakan 

suplemen ampas tempe dan ampas kecap. Hal ini sesuai dengan konsumsi BK pakan pada masing-masing perlakuan serta kandungan energi (TDN) yang dimiliki, berturut-turut yaitu 70,$35 ; 52,01$ dan 32,94\%. Seperti dinyatakan oleh Parakkasi (1999) bahwa dengan memprediksi kadar energi bahan pakan akan dapat pula digunakan untuk memprediksi konsumsi BK pakan maupun konsumsi energi (TDN). Semakin tinggi nilai energi suatu ransum maka akan meningkatkan konsumsi energi.

\section{Pertambahan Berat Badan Harian}

Hasil analisis koNariansi menunjukkan bahwa PBBH dari keempat macam perlakuan adalah berbeda sangat nyata $(\mathrm{P}<0,01)$, hal ini berarti bahwa $\mathrm{PBBH}$ sangat dipengaruhi oleh macam perlakuan pakan suplemen. Hasil uji lanjut Duncan menunjukkan bahwa rerata pertambahan berat badan harian antara $\mathrm{P} 0$ dengan $\mathrm{P} 1$ dan $\mathrm{P} 2$ berbeda sangat nyata $(\mathrm{P}<0,01)$, tetapi dengan P3 berbeda tidak nyata. Sedangkan antara P1 dengan P2 berbeda tidak nyata tetapi antara P3 dengan $\mathrm{P} 1$ dan $\mathrm{P} 2$ berbeda sangat nyata $(\mathrm{P}<0,01)$.

Domba dengan pakan suplemen berupa ampas tahu mempunyai rerata PBBH paling tinggi, tetapi secara statistik berbeda tidak nyata dengan domba dengan pakan suplemen berupa ampas tempe. Hal ini disebabkan konsumsi BK, PK dan energi pada kelompok domba ini juga tinggi. Menurut Handayanta (2004) pertambahan bobot badan berkaitan dengan konsumsi BK, konsumsi protein dan konsumsi energi. Dijelaskan lebih lanjut oleh Tillman et al. (1991) bahwa semakin tinggi konsumsi BK, maka semakin banyak nutrien vang dikonsumsi yang akan digunakan untuk pertumbuhan dan produksi sehingga berpengaruh pada bobot badan. Wiradisastra dan Usri (1980) cit Tarmidi (2004) menyatakan bahwa salah satu komponen nutrien pakan yang penting untuk pertambahan bobot badan ternak adalah protein. Tingginva pertambahan bobot badan berbanding lurus dengan kandungan PK dalam ransum yang dikonsumsi.

Domba dengan pakan suplemen berupa ampas kecap mempunvai rerata PBBH paling rendah, tetapi secara statistik berbeda tidak nyata dengan domba tanpa pakan suplemen. Hal ini diduga ampas kecap mempunyai kualitas nutrien yang rendah meskipun kandungan PK relatif tinggi. Afzalani et al. cit. Sunarso (1984) menyatakan bahwa ampas kecap mempunyai komponen mudah larut dan nilai efektif degradasi PK yang tinggi. yaitu 89,16\%. Kondisi ini menunjukkan bahwa ampas kecap mempunyai sifat kelarutan yang tinggi serta protein ampas kecap tidak tahan terhadap degradasi mikroba rumen akibatnya protein pasca rumen menjadi rendah. Siregar (1994) menyatakan bahwa bahan pakan yang dapat digunakan sebagai komponen ransum, ada yang mudah larut dan ada pula yang sukar mengalami degradasi di dalam rumen. Ternak ruminansia produksinva tinggi sebaiknya menggunakan ransum dengan protein yang sedikit di degradasi dalam rumen.

\section{Konversi Pakan}

Hasil analisis variansi menunjukkan bahwa konversi pakan dari keempat macam perlakuan adalah berbeda sangat nvata $(\mathrm{P}<0,01)$. Hal ini berarti bahwa konversi pakan sangat dipengaruhi oleh macam perlakuan pakan suplemen. Hasil uji lanjut Duncan menunjukkan bahwa rerata konversi pakan antara P0 dengan P1 dan P2 berbeda tidak nyata, tetapi ketiganya berbeda sangat nyata $(\mathrm{P}<0,01)$ dengan $\mathrm{P} 3$.

Domba dengan pakan suplemen berupa ampas kecap mempunyai nilai konversi pakan paling besar dan secara statisitik berbeda sangat nyata $(\mathrm{P}<0,01)$ 

dengan nilai konversi pakan pada kelompok domba lainnya. Hal ini disebabkan konsumsi BK, konsumsi protein, konsumsi energi dan PBBH domba, dimana konsumsi BK konsumsi protein dan konsumsi energi pakan yang semakin tinggi tidak mampu meningkatkan PBBH domba. Konversi pakan menurut Preston and Willis (1974) cit. Julianto (2003) merupakan perbandingan antara jumlah pakan yang dikonsumsi dengan pertambahan berat badan harian yang dihasilkan dalam satuan vang sama. Kelompok domba dengan pakan suplemen ampas tahu mempunyai nilai konversi pakan paling kecil, meskipun secara statistik berbeda tidak nyata dengan domba dengan pakan suplemen ampas tempe dan domba tanpa pakan suplemen. Hal ini menunjukkan bahwa suplementasi ampas tahu semakin efisien dalam menghasilkan pertambahan berat badan. Handayanta (1994) menyatakan bahwa semakin kecil nilai konversi pakan, berarti semakin rendah ransum yang diperlukan untuk menghasilkan produk (daging) dalam satuan yang sama.

\section{KESIMPULAN}

Kesimpulan yang dapat diambil dari hasil penelitian ini adalah ampas tahu dan ampas tempe dapat meningkatkan performan, sedangkan ampas kecap tidak dapat meningkatkan perforrnan domba lokal jantan.

\section{DAFTAR PUSTAKA}

Anonimous. 1980. Laporan Inventarisasi Potensi dan Pemanfaatan Limbah Industri Pertanian. Fapet IPB dan Dit. Bina Prod. Peternakan. Ditjen Peternakan. Deptan, Jakarta.

Firdus., D. A. Astuti dan E. Wina, 2004. Pengaruh kondisi fisik kaliandra dan campurannya dengan gamal segar terhadap konsumsi dan kecernaan nutrien pada domba. J. Ilmu Ternak dan Veteriner. Pusat Penelitian dan Pengembangan Peternakan. Bogor. 9(1):12-16.

Handayanta, E. 1999. Pengaruh Suplementasi Onggok dan Ampas Tahu dalam Ransum terhadap Performan Domba. Laporan Penelitian Akademi Peternakan Karanganyar.

Handayanta, E. 2004. Pengaruh penggunaan ampas bir fermentasi dalam ransum terhadap kinerja sapi jantan peranakan Friesian Holstein. Sains Peternakan. J. Penelitian Ilmu Peternakan. Jurusan Produksi Ternak. Fakultas Pertanian. Universitas Sebelas Maret, Surakarta. 1(1):1-8.

Handayanta, E. 2004. Pengaruh substitusi rumput raja dengan pucuk tebu dalam ransum terhadap performan sapi jantan Friesian Holstein. Sains Peternakan, J. Penelitian Ilmu Peternakan. Jurusan Produksi Ternak Fakultas Pertanian Universitas Sebelas Maret, Surakarta. 1(2):49-56.

Hanafiah, A. K. 2000. Rancangan Percobaan Teori dan Aplikasi. PT. Raja Grafindo Persada, Jakarta.

Hartadi, H. S. Reksohadiprojo dan A. D. Tilman. 1990. Tabel Komposisi Pakan untuk Indonesia. Gadjah Mada University Press, Yogyakarta.

Julianto, L. T. L. 2003. Pengaruh pemberian urea molases blok sebagai pakan suplemen terhadap pertumbuhan pedet PFH jantan. Skripsi. Jurusan Peternakan. Fakultas Pertanian. Universitas Sebelas Maret, Surakarta.

Kamal. M. 1994. Nutrisi Ternak I. Fakultas Peternakan. Universitas Gadjah Mada, Yogyakarta.

Kartadisastra, H. R. 1997. Penyediaan dan Pengelolaan Pakan Ternak Ruminansia. Kanisius, Yogyakarta. 

Kearl, L. C. 1982. Nutrient Requirements of Ruminant in Developing Countries. International Feedstuffs Institute Utah Agriculture Experiment Station Utah State University, Logan Utah.

Parakkasi. A. 1999. Ilmu Nutrisi dan Makanan Ternak Ruminansia. Universitas Indonesia Press, Jakarta.

Siregar, S. B. 1994. Ransum Ternak Ruminansia. Penebar Swadaya, Jakarta.

Steel. R.G. dan J.H. Torrie. 1981. Principles and Procedures of Statistics. A. Biometrical Approach. $2^{\text {"d }}$ Ed. Mc. Graw-Hill Book Company. Singapore.

Sunarso. 1984. Mutu Protein Limbah Agro Industri Ditinjau dari Kinetika Perombakannya oleh Mikroba Rumen dan Potensinya dalam Menyediakan Protein Bagi Pencernaan Pasca Rumen. Fakultas Pasca Sarjana. 1PB, Bogor.

Tarmidi, A. R. 2004. Pengaruh pemberian ransum yang mengandung ampas tebu hasil biokonversi oleh jamur tiram putih (Pleurotus ostreatus) terhadap performan domba Priangan. J. Ilmu Ternak dan Veteriner. Pusat Penelitian dan Pengembangan Peternakan, Bogor. 9(3):157-163.

Tillman. A. D., H. Hartadi. S. Reksohadiprojo, S. Prawirokusumo dan S. Lebdosoekojo. 1991. Ilmu Makanan Ternak Dasar. Gadjah Mada University Press, Yogyakarta.

Wahju, J. 1992. Ilmu Nutrisi Unggas. Gadjah Mada University Press, Yogyakarta.

Wulandari. D. 2006. Pengaruh penggunaan Fermented Mother Liquor (FML) dalam ransum terhadap performan sapi peranakan Friesian Holstein dara. Skripsi. Jurusan Peternakan. Fakultas Pertanian. Universitas Sebelas Maret, Surakarta. 